\title{
PELAKSANAAN MANAJEMEN KURIKULUM 2013 PADA TINGKAT SEKOLAH DASAR DI KECAMATAN TANJUNG EMAS
}

\author{
Vera Defyanti \\ Guru SDN 29 Padang Datar Pagaruyung, Koresponden: \\ J orong Nan IV Pagaruyung Kecamatan Tanjung Emas, Kabupaten Tanah Datar, \\ e-mail: vdefyanti@yahoo.com \\ $+20$
}

\begin{abstract}
Implementation of Management Curriculum 2013 at the Elementary School in the Tanjung Emas District. The purpose of this study to describe the management curriculum at the elementary school 2013, and knowing the causes of curriculum policy 2013 and its implications for management in the primary school curriculum.

From the results of the study revealed that the implementation of the 2013 curriculum management in primary schools have not fully load a fundamental change of the curriculum. Fundamental change of curriculum in 2013 was the planting of religious attitudes and social behavior, learning developed through thematic integrative, Scientific approach, which requires authentic teacher assessment measure all competency as attitudes, skills, and knowledge based processes and outcomes, as well as the compulsory extracurricular Scout. This means that schools still require the maximum development of the 2013 curriculum management planning, implementation, controlling and evaluation of the curriculum should be implemented as well as possible.
\end{abstract}

Keywords: management curriculum, curriculum 2013

\section{Pendahuluan}

Keresahan besar yang sedang melanda dunia pendidikan Indonesia adalah krisis multi dimensi. Hal ini disebabkan karena rusaknya karakter yang berakar dari nilai-nilai luhur bangsa. Pendidikan sebagai media untuk mewariskan nilai-nilai luhur terhadap generasi penerus berjalan kurang optimal, sehingga nilai-nilai luhur yang seharusnya ditanamkan terhadap generasi muda tidak berhasil dicapai. Hasil survei internasional tentang kemampuan siswa Indonesia, juga menunjukkan hasil yang mengecewakan. Dalam Mulyasa (2013: 60) memuat hasil Trends in International Math and Science (TIMSS) oleh Global Institute pada tahun 2007 hanya 5 persen siswa Indonesia yang mampu mengerjakan soal berkategori tinggi yang memerlukan penalaran dan hasil Programme for International Student Assessment (PISA) di tahun 2009 menempatkan Indonesia di peringkat 10 besar paling belakang dari 65negara. Dari kedua hasil survey tersebut 
didapat informasi bahwa hal ini terjadi bukan karena pelajar Indonesia tidak mampu, namun disebabkan antara lain banyaknya materi uji yang ditanyakan di TIMSS dan PISA tidak terdapat dalam kurikulum Indonesia.

Menyadari pentingnya proses peningkatan kualitas sumber daya manusia, maka pemerintah berupaya mewujudkan amanat tersebut melalui berbagai usaha pembangunan pendidikan yang lebih berkualitas antara lain melalui pengembangan dan perbaikan kurikulum. Mengingat tantangan Abad 21 serta menyiapkan generasi emas tahun 2045. Pemerintah Indonesia melalui Kementerian Pendidikan dan Kebudayaan merumuskan kurikulum 2013.

Kurikulum 2013 merupakan kelanjutan dari Kurikulum Berbasis Kompetensi dan Kurikulum Tingkat Satuan Pendidikan yang telah dirintis sebelumnya dengan mencakup kompetensi sikap, pengetahuan, dan keterampilan secara terpadu. Titik tekan pengembangan kurikulum 2013 adalah penyempurnaan pola pikir, penguatan tata kelola kurikulum, pendalaman dan perluasan materi, penguatan proses pembelajaran, dan penyesuaian beban belajar agar dapat menjamin kesesuaian antara apa yang diinginkan dengan apa yang dihasilkan. Pengembangan kurikulum 2013 menitikberatkan pada penyederhanaan, melalui pendekatan tematikintegratif (Kompas.com (2013: 5 Juni 2013).

Bagi sekolah dasar yang menganut system guru kelas pembelajaran tematik integrative sangat memberi keuntungan antara lain: 1) Fleksibilitas pemanfaatan waktu dan menyesuaikannya dengan kebutuhan siswa, 2)
Menyatukan pembelajaran siswa, konvergensi pemahaman yang diperolehnya sambil mencegah terjadinya inkonsistensi antar mata pelajaran, 3) Merefleksikan dunia nyata yang dihadapi anak di rumah dan lingkungannya. 4) Selaras dengan cara anak berfikir, dimana menurut penelitian otak mendukung teori pedagogi dan psikologi bahwa anak menerima banyak hal dan mengolah dan merangkumnya menjadi satu. Sehingga mengajarkan secara holistik terpadu adalah sejalan dengan bagaimana otak anak mengolah informasi ( Implementaasi Kurikulum 2013, 2013:42).

Konsep Kurikulum 2013 adalah tazkiyah (attitude), tilawah (pengetahuan) dan táalim (keterampilan). Kurikulum ini juga merupakan kurikulum yang berbasis penguatan penalaran. Kemendikbud menyebutkan elemen perubahan yang terdapat dalam kurikulum 2013 selain yang telah disebutkan di atas antara lain : 1) Adanya peningkatan dan keseimbangan soft skills dan hard skills yang meliputi aspek kompetensi sikap, keterampilan, dan pengetahuan, 2) Mata pelajaran dirancang terkait satu dengan yang lain dan memiliki kompetensi dasar yang diikat oleh kompetensi inti tiap kelas, 3) Terjadi pengurangan matapelajaran yang harus diikuti siswa namun jumlah jam bertambah $1 \mathrm{JP} /$ minggu akibat perubahan pendekatan pembelajaran, 4) Proses Pembelajaran menggunakan Pendekatan Saintifik dan Kontekstual, 5) Proses Penilaian menggunakan Penilaian Otentik (Autentic Asesment), 6) Terdapat ekstra kulikuler di SD antara lain Pramuka (wajib), UKS, bahasa Inggris dll (Mulyasa, 2014: 60). 
Tujuan kurikulum 2013 adalah untuk mempersiapkan manusia Indonesia agar memiliki kemampuan hidup sebagai pribadi dan warga negara yang beriman, produktif, kreatif, inovatif, dan afektif serta mampu berkontribusi pada kehidupan bermasyarakat, berbangsa, bernegara, dan peradaban dunia. Dalam mencapai tujuan besar kurikulum 2013 tersebut, peran sekolah sebagai ujung tombak implementasi kurikulum sangat penting. Untuk itu pelaksanaan manajemen kurikulum di sekolah adalah kunci dari segalanya. Maria Mumpuni dari Benih Matahari dalam Fokus.news.viva.co.id ( 2013:5 Juni 2013) menegaskan tidak ada perbedaan mencolok antara Kurikulum KBK, KTSP dan 2013. "Namun demikian, dia melihat ada tiga aspek yang menjadi ruh setiap kurikulum yaitu materi, peran guru dan peran kepala sekolah serta manajemen kurikulum yang dilaksanakan di sekolah.

Kurikulum merupakan salah satu substansi manajemen sekolah yang sangat vital. Oleh karena itu, kurikulum perlu dikelola dengan sebaik-baiknya. Dan dalam proses pendidikan perlu dilaksanakan manajemen kurikulum agar perencanaan, pelaksanaan, pengawasan dan evaluasi kurikulum berjalan lebih efektif, efisien, dan optimal dalam memberdayakan berbagai sumber belajar, pengalaman belajar, maupun komponen kurikulum (Rusman, 2009:3). menjelaskan manajemen kurikulum adalah sebagai suatu sistem pengelolaan kurikulum yang kooperatif, komprehensif, sistemik, dan sistematik dalam rangka mewujudkan ketercapaian tujuan kurikulum. Hal ini sejalan dengan tujuan dari manajemen kurikulum yang terdiri atas : 1) Pencapaian pengajaran dengan menitik beratkan pada peningkatan kualitas interaksi belajar mengajar.2) Mengembangkan sumber daya manusia dengaan mengacu pada pendayagunaan seoptimal mungkin.3) Pencapaian visi dan misi pendidikan nasional.4) Meningkatkan kualitas belajar mengajar disuatu pendidikan tertentu.

Secara umum fungsi-fungsi manajemen kurikulum dapat dikemukkan sebagai berikut: yaitu :1) Mengelola perancangan (desain) kurikulum pembelajaran, 2) Mengelola implementasi kurikulum pembalajaran, 3) Mengelola pelaksanaan evaluasi kurikulum pembelajaran, 4) Mengelola perumusan penetapan criteria dan pelaksanaan kurikulum kelas/kelulusan, 5) Mengelola pengembangan bahan ajar, media, dan sumber belajar, 6) Mengelola pengembangan kokurikuler dan ekstrakurikuler, 7) Mengelola penerapan uji coba atau merintis pembelajaran yang dicanangkan pemerintah (Rusman, 2009:34).

Tugas dan peran kepala sekolah dalam manajemen kurikulum secara umum terdapat pada peraturan mentri pendidikan Nasional No.13 tahun 2007 tentang standar kepala sekolah/madrasah yang salah satunya adalah kompetensi manajerial. Khusus dalam implementasi kurikulum 2013 seorang kepala sekolah harus memiliki strategi dalam melaksanakan manajemen kurikulum di sekolah agar peserta didiknya memiliki kompetensi pada dimensi sikap, pengetahuan dan keterampilan sesuai dengan Standar Kompetensi kelulusan (SKL) yang merupakan acuan utama dalam pengembangan standar isi, standar proses, standar penilaian pendidikan, 
standar pendidik dan tenaga kependidikan, standar sarana dan prasarana, standar pengelolaan, dan standar pembiayaan. Untuk itu manajemen untuk perubahan dan budaya sekolah menjadi perhatian utama.

Dari data awal yang penulis temukan dari berbagai sumber, sangat terlihat kurangnya pelaksanaan manajemen kurikulum di Sekolah Dasar. Hal ini tergambar dari belum mampunya sekolah menyusun RKS yang dapat menunjang pelaksanaan kurikulum, rendahnya kemampuan guru dalam mengimplementasikan kurikulum baru. rendahnya pelaksanaan intra kurikuler dan ekstra kurikuler yang menunjang kurikulum di sekolah. (Fokus.news.viva.co.id : 2 April 2013). Masalah-masalah pelaksanaan manajemen di sekolah khususnya di sekolah dasar yang telah peneliti kemukakan di atas, melatarbelakangi keinginan peneliti untuk mencermati dan mengkaji secara lebih mendalam tentang Pelaksanaan Manajemen Kurikulum 2013 Pada Tingkat Sekolah Dasar dan untuk tempat penelitian, peneliti memilih lokasi di Kecamatan Tanjung Emas.

\section{METODE}

Penelitian ini menggunakan pendekatan kualitatif. Jenis penelitian pada penelitian ini adalah penelitian kebijakan. Penelitian kebijakan merupakan penelitian yang melihat dampak yang ditimbulkan oleh adanya kebijakan dari sudut pandang ilmiah dengan cara mengumpulkan informasi secara kompresensif untuk dideskripsikan dan dianalisis secara logis, sistematis, dan objektif (A.H. Hanafi, 2013:167).
Pertanyaan penelitian merupakan hal yang penting untuk dalam mengungkapkan dampak dari kebijakan kurikulum 2013, dan dijabarkan lebih lanjut melalui pertanyaanpertanyaan sebagai berikut: (1) Bagaimana deskripsi manajemen kurikulum Sekolah Dasar sebelum ada kurikulum 2013? (2) Bagaimana deskripsi manajemen kurikulum Sekolah Dasar setelah ada kurikulum 2013? (3) Apa penyebab timbulnya kebijakan kurikulum 2013 dan implikasinya terhadap manajemen kurikulum di Sekolah Dasar dalam menghadapi kurikulum 2013?

Tempat penelitian yang dijadikan objek untuk memperoleh data penelitian pada penelitian ini adalah SD Negeri yang telah melaksanakan kurikulum 2013 di Kecamatan Tanjung Emas yang terdiri dari 4 SDN dengan rincian: SDN 02 Pintu Rayo Tajung Barulak, SDN 05 Koto Tangah, SDN 22 Balai Janggo Pagaruyung, dan SDN 29 Padang Datar Pagaruyung. Waktu dalam penelitian ini direncanakan terlaksana selama 3 bulan. Dimulai pada bulan Mei sampai dengan bulan Juli 2014.

Dalam penelitian ini metode yang digunakan dalam mengumpulkan data adalah 1) Metode Interview atau Wawancara, 2) Observasi partisipan, 3) Peristiwa atau aktivitas, 4) Dokumen dan Arsip. Setelah data terkumpul dilanjutkan dengan analisis data. Analisis data dalam penelitian kualitatif merupakan proses penyederhanaan data ke dalam bentuk yang mudah dibaca dan diinterprestasikan. Penelitian kualitatif memandang data sebagai produk dari proses memberikan interprestasi peneliti yang di 
dalamnya sudah terkandung makna yang mempunyai referensi pada nilai. Untuk jenis penelitian dengan pendekatan kualitaif, menurut Miles dan Huberman ( 1990: 16) ada tiga tahapan data, yakni: reduksi data, penyajian data dan penarikan kesimpulan/ verifikasi.

\section{PEMBAHASAN}

\section{Data Sebelum Pelaksanaan Kurikulum 2013}

Sebelum pelaksanaan kurikulum 2013, Sekolah Dasar melaksanakan Kurikulum Tingkat Satuan Pendidikan (KTSP). Pelaksanaan manajemen kurikulum KTSP di Sekolah Dasar masih mengalami banyak kendala, Dalam mengelola perencanaan / perancangan KTSP untuk tahun ajaran baru, semua sekolah telah melaksanakannya di awal libur sekolah. Dalam KTSP sekolah diberi kebebasan mengembangkan indicator dan materi pembelajaran. Namun semua sekolah dalam pengembangan kurikulum belum sesuai dengan prinsip pengembangan KTSP karena keterbatasan waktu dan kemampuan kepala sekolah dan guru. Hal ini dapat dilihat dari keterangan salah satu kepala sekolah yang juga diamini oleh kepala sekolah lain, yang menyatakan

Dalam pelaksanaan penyusunan KTSP berdasarkan prinsip-prinsip yang telah ditetapkan kami merasa kesulitan melaksanakannya secara menyeluruh, pertama karena pelaksanaan evaluasi bersama di kecamatan untuk ujian tengah semester dan ujian semester. Dan hal yang paling berat adalah masih adanya pelaksanaan Ujian
Nasional. Jadi sekolah lebih focus pada kisikisi Ujian Nasional. Pada saat ini sekolah hanya menyesuaikan prinsip pengembangan tersebut pada kegiatan ekstrakurikuler dan penetapan KKM kelas. Untuk dokumen I dan II KTSP kami berpedoman pada dokume lama.( NM, 16-06-2014)

Salah seorang guru juga berpendapat yang sama yang menyatakan bahwa:

Kami agak takut jika berbeda dengan sekolah lain, dalam mengembangkan kurikulum, karena sistem ujian bersama masih ada. Jangan sampai peserta didik dirugikan karena salah menurunkan indicator dari setiap kompetensi dasar, untuk itu guru selalu berkoordinasi dengan guru-guru sekolah lain. Namun untuk pelaksanaan ekstrakurikuler kami berpedoman pada kemampuan sekolah dan minat peserta didik kami. (DN, 16-06-2014)

Dalam pelaksanaan pembelajaran guru masih kesulitan melaksanakan pembelajaran sesuai dengan karakteristik KTSP seperti pembelajaran eksplorasi, elaborasi, dan konfirmasi serta penanaman karakter karena muatan materi yang banyak. Penggunaan media pembelajaranpun masih perlu ditingkatkan, walaupun dalam pengadaan sekolah telah berusaha mencukupinya. Untuk pelaksanaan ekstrakurikuler dan pembiasaan telah berjalan cukup baik, namun perlu ditingkatkan. Tapi ada sekolah yang telah memperlihatkan prestasi dalam ekstrakurikuler dan pembiasaan sekolah. Hal ini diungkapkan oleh salah seorang kepala sekolah, yang menyatakan:

Saya selalu membuat program bagi guru yang pulang pelatihan untuk berbagi ilmunya 
dengan teman. Ditambah lagi ada kegiatan KKG bermutu yang diikuti intensif oleh semua guru. Namun pelaksanaan pembelajaran sesuai KTSP masih berjalan 60\%, masih ada yang melaksanakan pembelajaran berpusat pada guru. Untuk sarana prasarana di sekolah juga baik. Saya sering adakan rapat atau pertemuan yang bertujuan meningkatkan motivasi dan komitmen guru. Untuk kegiatan ekstra di sekolah ini telah berjalan baik, karena kami menunjuk guru khusus yang menangani setiap program, seperti computer, olah raga, UKS dan pramuka. Untuk program pembiasaan di sekolah K3 (Kebersihan, Ketertiban dan keindahan) menjadi program utama. Dengan kebiasaan ini sekolah kami mendapat penghargaan mewakili Sumatera Barat mengikuti sekolah sehat tingkat nasional. (NM, 16-06-2014)

Mengenai pelaksanaan kontroling dan evaluasi keempat sekolah memperlihatkan hal yang hampir sama, pelaksanaan kontroling yang dilaksanakan dengan supervise tidak diikuti dengan tindak lanjut sehingga perbaikan pembelajaran yang diharapkan tidak terjadi. Begitu juga halnya dengan evaluasi. Hasil evaluasi peserta didik seharusnya dapat menjadi bahan untuk mengevaluasi kinerja guru, serta dapat menjadi langkah untuk membuat perencanaan ke depan.

\section{Data Sesudah Kebijakan Kurikulum 2013}

Pelaksanaan manajemen kurikulum 2013 di Sekolah Dasar pada dasarnya belum memperlihatkan perubahan yang siknifikan sesuai dengan karakteristik kurikulum 2013. Dalam perencanaan kurikulum, dari data yang didapat belum semua perubahan yang terjadi pada kurikulum 2013 dimuat dalam perencanaan sekolah, Hasil wawancara dengan salah satu kepala sekolah didapat informasi:

Perencanaan pembelajaran pada kurikulum 2013 tidak dapat kami programkan seperti biasa karena pelatihan baru dilaksanakan ketika libur semester II. Jarak antara pelatihan dengan pelaksanan kurikulum sangat dekat. Jadi, kami membuat perencanaan setelah selesai mengikuti pelatihan. Namun perencanaan kurikulum 2013 tidak terlalu sulit seperti KTSP karena silabus telah ditetapkan. Buku guru benarbenar memandu pelaksanaan pembelajaran setiap harinya, sehingga guru bisa berpedoman ke buku guru untuk membuat perangkat pembelajaran. Untuk pelaksanaan kurikulum 2013 sekolah dituntut untuk menyiapkan program untuk kesuksesan kurikulum 2013 seperti pembinaan kegiatan pembelajaran, ekstrakurikuler dan budaya sekolah serta sosialisasi kurikulum 2013, namun belum semua bisa direncanakan. (YK, 28-06-2014)

Mengenai pelaksanaan kurikulum 2013 guru berpedoman sepenuhnya pada buku guru dan buku siswa. Hal ini cukup membantu pelaksanaan pembelajaran tematik dengan pendekatan Scientific. Namun masih ada ditemukan guru yang belum melaksanakan pembelajaran menurut karakteristik kurikulum 2013. Informasi dari wawancara dengan salah seorang kepala sekolah menyatakan

Dalam melaksanakan kurikulum kemampuan guru menjadi kunci utama. Pelatihan kurikulum 2013 telah diikuti oleh semua guru. Namun karena di sekolah ada 
salah seorang guru kami yang menjadi guru inti kurikulum 2013 saya membuat kegiatan bagi guru yang mengikuti pelatihan untuk mengembangkan ilmunya kembali di sekolah. Dengan demikian semua guru di sekolah memiliki tambahan pengetahuan. Penggunaan buku guru dan buku siswa sangat mendukung pelaksanaan kurikulum 2013. Pelaksanaan pembelajaran yang dijelaskan secara rinci membuat guru mudah mengikutinya. Hal yang perlu diperbaiki dari buku guru dan buku siswa adalah muatan materi yang dangkal sehingga saya selalu meminta guru untuk menambah bahan ajar dari sumber lain. Pelaksanaan pembelajaran dengan pengimplementasikan Kompetensi Inti 1,2 dan 4 masih butuh peningkatan. Guru-guru kita sering lupa mengaitkan materi dengan sikap keagamaan dan sikap social peserta didik. Kegiatan selama ini masih tetap berjalan karena telah sesuai dengan kurikulum 2013. Visi, misi, dan tujuan sekolah yang telah ditetapkan menjadi acuan bagi kami untuk bekerja. Program ekstrakurikuler Pramuka tetap berjalan seperti biasa yaitu setiap hari (YL, 2-7-2014)

Dalam pelaksanaan kontroling keadaannya pun tidak jauh berbeda dengan pelaksanaan kontroling pada KTSP. Umpan balik setelah pelaksanaan kontroling/supervise yang sangat penting masih sering ditinggalkan oleh kepala sekolah. Ini dapat dilihat dari informasi yang disampaikan salah seorang guru yang menyatakan:

Saya lihat di sekolah kegiatan dalam pengawasan masih perlu peningkatan. Setelah melaksanakan supervise terkadang kita tidak diberitahu umpan baliknya.
Apakah pembelajaran kita sudah baik atau perlu peningkatan. ( Abd,8-7- 2014)

Pelaksanaan evaluasi juga terkesan demikian. Evaluasi pembelajaran peserta didik yang dilakukan dengan penilaian autentik masih sulit dilaksanakan oleh guru terutama pada aspek keterampilan. Untuk evaluasi kerja guru belum terjadi sehingga sekolah belum punya perencanaan untuk peningkatan pelaksanaan kurikulum 2013 ke depan.

Dalam pelaksanaan penilaian atau evaluasi terhadap proses pelaksanaan pembelajaran yang dilaksanakan oleh guru sesuai bidang studi dan kelasnya masing-masing pada kurikulum ini menggunakan penilaian otentik yaitu mengukur semua kompetensi sikap, keterampilan, dan pengetahuan berdasarkan proses dan hasil. Saya lihat guru saya sudah mampu mengumpulkan nilai dari semua aspek, walaupun masih perlu meningkatkan aspek keterampilan yaitu menghasilkan karya. . Namun dalam pelaporan penilaian secara deskriptif membuat guru harus bekerja keras karena ulangan biasanya berdasarkan tema, namun ketika dilaporkan harus berdasarkan muatan pelajaran.(Jasmiati, 9-7-2014)

Perubahan yang mendasar dari kurikulum ini seperti Pendekatan kompetensi yang dikembangkan melalui tematik integratif, Standar proses yang menggunakan pendekatan Scientific, penilaian otentik yang mengharuskan guru mengukur semua kompetensi sikap, keterampilan, dan pengetahuan berdasarkan proses dan hasil, dan Ekstrakulikuler wajib Pramuka. Pelaksanaan manajemen kurikulum 2013 sangat dibutuhkan di sekolah. Prof. Dr. Ir. H. Musliar Kasim, MSi, menyatakan bahwa: 
Kepala sekolah perlu memahami berbagai komponen perubahan yang seharusnya terjadi dalam menerapkan kurikulum 2013. Pergeseran dalam standar SKL, isi, proses, dan penilaian perlu dicermati dengan seksama. Yang perlu mendapat perhatian utama ialah memilih prioritas komponen sistem yang perlu berubah, memetakan kondisi saat ini dan kondisi yang diharapkannya. Dengan dasar itu, kepala sekolah dapat menentukan strategi untuk mewujudkan kondisi yang diharapkan sehinga semua tindakan penting yang akan kepala sekolah laksanakan terencana. Di antaranya adalah mengembangkan struktur kurikulum sekolah sesuai dengan kebutuhan siswa. Pekerjaaan ini perlu didahulukan mengingat sekolah dapat menambah jam belajar sehingga sesuai dengan kebutuhan siswa untuk berprestasi. Dengan adanya struktur yang sesuai dengan kebutuhan sekolah dapat mengembangkan kalender pendidikan dan peta beban belajar siswa yang dapat mendukung terwujudnya mutu lulusan. Pemetaan beban belajar perlu melibatkan seluruh pendidik mengingat banyaknya karya yang harus siswa kerjakan yang tersebar dalam berbagai mata pelajaran sebagai konsekuensi dari kurikulum 2013 berbasis aktivitas dan karya.. (Musliar Kasim, 27-1-2013)

Pelaksanaan kurikulum 2013 mengharapkan adanya pembelajaran tematik dengan pendekatan Scientific. Buku guru dan buku siswa menjadi panduan dalam pelaksanaan kurikulum 2013, namun untuk metode pembelajaran guru harus tetap berusaha mencari metode yang sesuai dengan karakteristik siswa dan selalumembangun karakter. Pelaksanaan kontroling yang diharapkan adalah adanya kegiatan kontrol yang diiringi oleh umpan balik dari observasi yang dilakukan. Selanjutnya evaluasi pembelajaran peserta didik dilakukan dengan penilaian otentik yang meliputi penilaian sikap, pengetahuan dan keterampilan, harus dilakukan dengan maksimal.

\section{PENUTUP}

\section{Kesimpulan}

Dari penelitian ini dapat disimpulkan, masih rendahnya pelaksanaan manajemen kurikulum 2013 di sekolah dasar. Dalam perencanaan sekolah belum memuat perubahan-perubahan yang harus dilaksanakan dalam kurikulum 2013, dalam implementasi kurikulum sekolah belum melaksanakan pembinaan bagi guru untuk pembelajaran tematik dengan pendekatan Scientific, penanaman karakter peserta didik, dan pembinaan ekstrakurikuler. penyediaan media, buku guru dan buku siswa serta sarana prasarana yang menunjang pembelajaranpun telah mulai dilaksanakan, namun masih jauh dari maksimal. Kontroling dalam implementasi kurikulum 2013 juga belum maksimal. Umpan balik dan tindak lanjut dari kontroling belum berjalan.Untuk pelaksanaan evaluasi autentik bagi peserta didik masih banyak menemukan kendala. Evaluasi bagi pelaksanaan kurikulum 2013 oleh guru juga belum berjalan maksimal.

\section{Saran}

Saran yang dapat disampaikan sebagai berikut:

a. Kepala sekolah, agar membuat perencanaan dengan matang sesuai dengan perubahan dan karakteristik kurikulum 2013, meminta komitmen, melakukan 
kontroling dan supervisi pembelajaran serta melakukan evaluasi terhadap penilaian otentik serta melaksanakan evaluasi terhadap pelaksanaan pembelajaran dan hasil kerja guru. Sehingga dapat dijadikan sebagai bahan perencanaan selanjutnya.

b. Guru, hendaknya mematuhi dan komitmen, membuat perencanaan pembelajaran tematik integratif, dengan pendekatan Scientific, penanaman karakter peserta didik, dan melaksanakan penilaian autentik.

c. Pengawas sekolah hendaknya memberikan pendampingan dan pembinaan

d. Pemerintah, agar mengadakan sosialisasi kurikulum 2013 serta mengembangkan grand design yang jelas,

\section{KEPUSTAKAAN ACUAN}

Abdul Halim Hanafi, Metodologi Penelitian Kependidikan, Batusangkar: STAIN Batusangkar Press, 2013
Edukasi. Kompas.com, Konsep Kurikulum 2013. Diakses tanggal 5 Juni 2013

Fokus.news.viva.co.id, Kurikulum 2013. Diakses tanggal 6 Juni 2013

[Kemdikbud] Kementerian Pendidikan dan Kebudayaan. Implementasi Kurikulum 2013, Jakarta: Kementerian Pendidikan dan Kebudayaan. 2013

Mulyasa, Pengembangan dan Implementasi Kurikulum 2013,Remaja Rosdakarya: Bandung, Cek.IV, 2014

Mathey Miles.B and Huberman, Qualitativ Data Analisys, Penterjemah: Rohendi Rohid, Jakarta : UI Press, 1992,

Rusman. Manajemen Kurikulum. Jakarta : PT RajaGrafindo Persada, 2009 